\title{
THE SUPREME COURT AS NATIONAL SCHOOL BOARD*
}

\author{
EDward S. CORWIN†
}

As a student at the University of Michigan a half century ago I had frequent occasion to attend convocations, lectures, and concerts in University Hall. Each time my eyes were confronted with the words, emblazoned on the wall over the great organ, "Religion, morality, and knowledge, being necessary to good government and the happiness of mankind, schools and the means of education shall forever be encouraged." These words are from the famous Northwest Ordinance which was enacted in 1787 by the last Congress of the Confederation, ${ }^{1}$ and which from the provision it makes for the establishment of public schools is the matrix of the public school system of a great part of the United States. Two years later many of the same men, representatives of the same people, sitting as the first Congress under the Constitution, proposed the following amendment to the Constitution: "Congress shall make no law respecting an establishment of religion, or prohibiting the free exercise thereof. ..." Do these words represent a fundamental change in attitude on the part of the American people on the question of what relation should subsist between public education and the teaching of religion? Prima facie it seems doubtful, ${ }^{2}$ but that it is so, nevertheless, is the implication of the decision on March 8, I948, of the United States Supreme Court in Illinois ex rel. Vashti McCollum v. Board of Education of Champaign County. ${ }^{3}$

The facts and holding in the case may be set forth as follows:

A local board of education in Illinois agreed to the giving of religious instruction in the schools under a "released time" arrangement whereby pupils, whose parents signed "request cards," were permitted to attend religious-instruction classes conducted during regular school hours in the school building by outside teachers furnished by a religious council representing the various faiths, subject to the approval and supervision of the superintendent of schools. Attendance records were kept and reported to the school authorites in the same way as for other classes; and pupils not attending the religious instruction classes were required to continue their regular secular studies.

The Court held, in an opinion by BLACK, J., that this arrangement was in violation of the constitutional principle of separation of Church and State, as expressed in the First Amendment and made applicable to the states by the Fourteenth Amendment, and accordingly that the state courts below had acted erroneously in refusing relief to the com-

- This is a revision of an article published in 43 THougrt 665 (I948).

tMcCormick Professor of Jurisprudence (emeritus), Princeton University.

${ }^{2}$ July 13, I787, I StaT. 5T, n., Art. III.

2 The doubt becomes doubly doubtful when we recall that Congress re-enacted the Northwest Ordinance in $179 \mathrm{r}$ !

${ }^{3} 333$ U. S. 203 (1948). 
plainant, parent and taxpayer, against the continued use of school buildings for such religious instruction.

This conclusion was supported further in a separate concurring opinion by FRANKFURTER, J., in which the historical backgrounds of the principle of separation of Church and State, and of "released time" arrangements, are considered at length. Justices JACKSON, RUTLEDGE, and BURTON joined in this opinion; and Justices RUT. LEDGE and BURTON also concurred in the opinion written by Justice BLACK.

JACKSON, $J$., in an additional opinion, although concurring in the result, expressed doubt as to the standing of the complainant to raise the question at issue, and also felt that the relief granted, prohibiting all religious instruction in the schools, was too broad and indefinite.

REED;" J., dissented on the ground that the co-operative "released time" arrangement did not involve either an "establishment of religion" or "aid" to religion by the state, sufficient to justify the Supreme Court in interfering with local legislation and customs."

The holding and the opinions accompanying it raise all sorts of questions. "Released time" programs prior to the decision operated in some 2,200 communities spread over forty-six states. ${ }^{5}$ Are all of these programs rendered unconstitutional by the ruling in the McCollum case, or only those which are conducted in public school buildings? Justice Frankfurter, after characterizing the Champaign plan as " $a$ conscientious attempt to accommodate the allowable functions of Government and the special concerns of the Church within the framework of our Constitution," says that some released-time programs may be constitutional, others unconstitutional, and which are the one or the other must await "close judicial scrutiny"7 as cases arise. From the point of view of persons vested with the responsibility of administering the public school system of the country, this is not exactly a consoling utterance. And positively disturbing to all public educational authorities, both those at the school level and those at the college and university level, is Justice Jackson's ${ }^{8}$ suggestion that the holding may contain a threat to courses on religion and religious history, or even to courses in art, philosophy, and literature, which can hardly be taught without reference to religion, the seed-bed of them all. ${ }^{9}$

In fact, the decision seems to have fully satisfied very few people. Even Mrs. McCollum is disappointed in the final outcome, to date, of her efforts. What she asked for was a judicial mandate that

would ban all teaching of the Scriptures. She especially mentions as an example of invasion of her rights "having pupils learn and recite such statements, "The Lord is my Shepherd, I shall not want." "And she objects to teaching that the King James version of the Bible "is called the Christian's Guide Book, the Holy Writ and the Word of God," and many other similar matters. ${ }^{10}$

92 L. Ed. 45 I (1948).

- McCollum v. Board of Education, 333 U. S. 203, 224-225 n. I6 (1948).

'Id. at 213. IId. at 225 . Id. at 236.

A great many state constitutional provisions seem likely to undergo Supreme Court scrutiny under the McCollum decision. See Frederic J. Strmson, The Law of the Federal and State Constitutions of THE UntTed States III, $\$ 2-48$ (1908).

${ }^{10} \mathrm{McC}$ Collum v. Board of Education, supra note 5, at 234-235. 
She also avows a distaste for the word "sin." Yet all that the Court did was to remand the cause to the State Supreme Court "for proceedings not inconsistent with this opinion,"11 a directive with which the latter court complied by banning the Champaign system. Comments the lady, according to the Champaign NewsGazette:

I am right back where I started from three years ago. I have wasted all this time and money without an order prohibiting the schools from aiding and abetting in carrying on these classes. The schools should be definitely ordered against corralling students for religious classes. I told Mr. Dodd [her attorney] that I was dissatisfied and wanted to appeal. I believe we will take any further action that is open to us. ${ }^{12}$

$\mathrm{My}$ interest in this case is, however, not in the question of its practical soundness, but in that of its constitutional soundness; in the question, in brief, whether the Constitution does require that all public-supported education be kept strictly secular. Some comparatively recent decisions suggest the contrary. In the New Jersey Bus case, ${ }^{13}$ which was decided thirteen months prior to the Champaign case, it was held that the state is not inhibited from aiding religious instruction incidentally to the exercise by it of the police power for the protection of the health and safety of school children on the way to school; while in I930, in Cochran v. Louisiana, ${ }^{14}$ it was held that children attending parochial schools could be made beneficiaries of that state's free textbook law without offense to the Constitution. The interest of the statute, said the Court, "is education, broadly; its method comprehensive. Individual interests are aided only as the common interest is safeguarded."15 Federal appropriations in support of free lunches for school children embrace parochial schools, presumably on the same justification. The parochial school is regarded as a distributing agency of social benefit, including education. Are these holdings invalidated by the McCollum decision?

We encounter the characteristic almost at the outset of Justice Black's "Opinion of the Court" in his brusque dismissal of the question whether Mrs. McCollum's own interest in the constitutional issue raised by her was sufficient to entitle the Supreme Court, under the rules governing judicial review, to decide it. ${ }^{16}$ The basic principle involved was stated by Justice Sutherland for the Court a quarter of a century ago, in these words:

We have no power per se to review and annul acts of Congress on the ground that they are unconstitutional. That question may be considered only when the justification for some direct injury suffered or threatened, presenting a justiciable issue, is made to rest upon such

11 Id. at $2 \times 2$.

${ }^{12}$ Speech delivered before National Council of Catholic Women, Convention in New Orleans, September II, 1948, by George E. Reed of Washington, member of the Council's legal department.

${ }^{13}$ Everson v. Board of Education, 330 U. S. I (x947).

14281 U. S. 370 ( 1930 ).

${ }^{28} \mathrm{Id}$. at 375 .

${ }^{20}$ McCollum v. Board of Education, stpra note 5, 2t 206-207. 
an act. Then the power exercised is that of ascertaining and declaring the law applicable to the controversy. It amounts to little more than the negative power to disregard an unconstitutional enactment, which otherwise would stand in the way of the enforcement of a legal right. The party who invokes the power must be able to show not only that the statute is invalid but that he has sustained or is immediately in danger of sustaining: some direct injury as the result of its enforcement, and not merely that he suffers in some indefinite way in common with people generally. ${ }^{17}$

The McCollum case originated, to be sure, in the courts of Illinois and was decided by them prior to its appeal to the Supreme Court, on writ of certiorari; but that fact does not alter the situation so far as the question above posed is concerned. In the words of Justice Frankfurter, dealing in 1939 in the case of Coleman $\nu$. Miller $^{18}$ with a situation which was on all fours with the one before us:

To whom and for what causes the courts of Kansas [sc. Illinois] are open are matters for Kànsas to determine. But Kansas can not define the contours of the authority of the federal courts, and more particularly of this Court. It is our ultimate responsibility to determine who may invoke our judgment and under what circumstances. . . .

It is not our function, and it is beyond our power, to write legal essays or to give legal opinions, however solemnly requested and however great the national emergency. . . our exclusive business is litigation. The requisites of litigation are not satisfied when questions of constitutionality though conveyed through the outward forms of a conventional court proceeding do not bear special relation to a particular litigant. The scope and consequences of our doctrine of judicial review over executive and legislative action should make us observe fastidiously the bounds of the litigious process within which we are confined. No matter how seriously infringement of the Constitution may be called into question, this is not the tribunal for its challenge except by those who have some specialized interest of their own to vindicate, apart from a political concern which belongs to all. ${ }^{19}$

While these words are from a dissenting opinion, they voice on this particular issue the views of the Court as a whole, as is shown by its explicit ruling that Coleman had a sufficient interest to entitle him to prosecute the case before it. In the McCollum case, nevertheless, Justice Black brushes aside the question of the materiality of Mrs. McCollum's interest in these curt words: "A second ground for the motion to dismiss is that the appellant lacks standing to maintain the action, a ground which is also without merit. Coleman v. Miller, 307 U. S. 433, 443, 445, 464."20 The passages thus cited in no wise challenge Justice Sutherland's position;

${ }^{1 \tau}$ Frothingham v. Mellon, 262 U. S. 447,488 (x923). (Italics supplied.) It should be noted that formerly the vast majority of constitutional cases arose out of the effort of some official agency or of some private individual to enforce legislation which the defendant in the case attacked as unconstitutional. There can be no doubt as to the special interest of such a defendant in having the constitutional question passed upon. The practice which has developed within the last half century of raising the question of constitutionality in suits for injunctions alters the picture somewhat. But it is as to taxpayers' suits that the doctrine of direct or special injury is most evidently relevant. See I6 C. J. S. Constitutional Law, $\$ \$ 76,80-82$ (1939).

${ }^{18} 307$ U. S. 433 (1939).

19 Id. at $462-464$. (Italics supplied).

${ }^{20}$ McCollum. Board of Education, stipra note 5, at 206. 
to the contrary, they assume its correctness. It is clear that the learned Justice had as much, and as little, right to cite Coleman v. Miller in support of his ruling as he would have had to invoke the Book of Revelations.

Of the remaining members of the Court sitting in the McCollum case, Justice Jackson alone expresses any qualms as to the right of the Court to exercise its jurisdiction. Comparing the case with the New Jersey School Bus case mentioned earlier, he says:

... in the Everson Case there was a direct, substantial and measurable burden on the complainant as a taxpayer to raise funds that were used to subsidize transportation to parochial schools. Hence, we had jurisdiction to examine the constitutionality of the levy and to protect against it if a majority had agreed that the subsidy for transportation was unconstitutional.

In this case, however, any cost of this plan to the taxpayers is incalculable and negligible. It can be argued, perhaps, that religious classes add some wear and tear on public buildings and that they should be charged with some expense for heat and light, even though the sessions devoted to religious instruction do not add to the length of the school day. But the cost is neither substantial nor measurable, and no one seriously can say that the complainant's tax bill has been proved to be increased because of this plan. I think it is doubtful whether the taxpayer in this case has shown any substantial property injury. ${ }^{21}$

"Incalculable and negligible" sums up with substantial accuracy the purport of the extensive finding of facts by the Circuit Court of Champaign County, in which Mrs. McCollum instituted her action. Besides, what of the opposed public interest -why should not that have been considered by the Court? In fact, it always has been considered in cases in which taxpayers have sought to challenge the constitutional validity of expenditures from the national fisc, with the result that no such challenge has succeeded thus far. ${ }^{22}$ Why the same rule should not be observed in the case of local expenditures is hard to see; and especially disappointing is the indifference shown on this occasion by those two or three members of the Court who have so frequently in recent years protested their love for the federal system and deplored its impairment.

I should like to point out, moreover, that a strange difference appears to exist today between public school buildings and public parks in respect to their availability for religious uses. In the Lockport case, ${ }^{23}$ which was decided three months after the McCollum case, it was held by a vote of five justices to four that an ordinance of the city of Lockport, New York, which forbids the use of sound amplification devices except with the permission of the chief of police was unconstitutional as applied in the case of a Jehovah's Witness who used sound equipment to amplify lectures in a public park on Sunday, on religious subjects. The proposition for which the case seems to stand is that when a municipality establishes a public park it thereby renders the park a potential forum for any blatherskite politician or

${ }^{2 x}$ Id. at 233-234. See also Transcript of Record, p. 69. The state Supreme Court agreed. Id. at 274-275.

"Sce note 17 supra.

${ }^{23}$ Saia v. New York, 334 U. S. 558 (1948). 
whirling deverish who wishes to peddle his doctrinal wares over a public address system, and that a park for quiet uses, to serve the amenities of civilized living, is unconstitutional..$^{23^{a}}$

At any rate, the discrepancy between the two holdings is apparent. In one it is held that a school board may not constitutionally permit religious groups to use on an equal footing any part of a school building for the purpose of religious instruction to those who wish to receive it. By the other the public authorities are under a constitutional obligation to turn over public parks for religious propaganda to be hurled at all and sundry whether they wish to receive it or not. The Court seems to cherish a strange tenderness for outré religious manifestations which contrasts sharply with its attitude toward organized religion.

But it appears that Mrs. McCollum had a second string to her bow, and that her appeal for the Court's protection was based also on her right and duty as parent. This ground for the Court's intervention is, if possible, even flimsier than the one just considered. What it simmers down to is the contention that plaintiff's son James Terry was subjected, in consequence of his non-participation in the program, to "embarrassment" and "humiliation." These allegations too, like those regarding the expense of the program, the court of first instance found to be unsubstantiated by "the great preponderance of evidence," a circumstance to which Justice Black makes no allusion. ${ }^{24}$ But even had the weight of testimony been otherwise, still the problem raised would seem to have been one of school discipline, to be settled in the principal's office, rather than one of constitutional interpretation for the Supreme Court at Washington. Besides, so far as anything to the contrary appears, had James Terry and his parent made proper application, the school authorities would have willingly assigned accommodations where the two of them might have foregathered during the released time period to confer with regard to their common faith-or lack of it. ${ }^{25}$

${ }^{233}$ In Kovacs $v$. Cooper, 336 U. S. 77, decided January 31, 1949, the Court sustained a Trenton Ordinance which banned from that city's streets all loud speakers and other devices which cmit "loud and raucous noises." The decision is asserted by three of the four dissenters to it to amount to a flat overruling of the decision in the Saia case, and I am inclined to agree with them. So much the better, say I. Justice Frankfurter's concurring opinion in the Kovacs case deserves special attention for its criticism of Justice Reed's reference, in his opinion for the Court, to "The preferred position of freedom of speech." Id. at 88. Justice Frankfurter follows a review of other similar dicta in recent opinions with the observation that the claim that any legislation which restrains "liberty" in the sense of the First and Fourteenth Amendments considered together, is "presumptively unconstitutional," "has never commended itself to a majority of this Court." Id. at 94-95. I wish to add that, even were it otherwise, still the Court would not be warranted in taking jurisdiction of a case which involved such a restraint, on the mere application of a person who had not shown sufficient direct injury because of the restraint in question.

${ }^{24}$ McCollum v. Board of Education, supra note 5, at 232. Transcript of Record, p. 68. It appears that Mrs. McCollum herself considers James 'Terry to be something of a "problem child," unable to get along with other children.

${ }^{25}$ This question occurs to me: Suppose that Jehovah's Witnesses' children should complain that they were "embarrassed," etc., in consequence of their not participating along with other school children in saluting the flag, would that render the salute requirement invalid for all school children? At least, their grievance would seem to be fully as substantial as James Terry's. 
To conclude this phase of the $M c$ Collum case-which may in the long run prove to be its most important phase-I wish to make two observations. The first is that Justice Black's brusque disposal of the question of Mrs. McCollum's locus standi in court to maintain her action reduces-or elevates-the doctrine of "special interest" to a jurisdictional fiction. All that anyone has to do to get the Court to pass on the constitutionality of a state statute or administrative order, under the First Amendment at any rate, is to allege that its enforcement will involve expense and that he is a taxpayer; neither of which allegations appears to be traversable, otherwise the Court must have paid some heed to the Illinois court's findings of fact. Whether the Court is wise in thus enlarging its jurisdiction in an area in which its performance has been in the past so obviously at the mercy of the individual prepossessions of its members, and is consequently so spotted with self-contradictions and inconsistencies, prompts a doubt-one which its holding in the case at bar is not calculated to dispel.

My second observation is advanced more diffidently. It is that under the principles governing award of mandamus, if the Champaign School Board had peremptorily refused the use of public school rooms for the released-time program, the backers of the plan would have had a far stronger case against the board than Mrs. McCollum had. Their combined interest in compelling a fuller use of public property to the creation and maintenance of which they contributed as taxpayers would have been impressive. Moreover, it would have been an affirmative interest. Mrs. McCollum, it seems to me, ought to have asked for an injunction, not mandamus.

\section{II}

People of the State of Illinois ex rel. Vashti McCollum, Appellant v. Board of Education of School District No. 71, Champaign County was welcomed by the Court with open arms, as affording it a grand opportunity to break a lance-or several of them-in behalf of the "constitutional principle"-as it is asserted to be-of Separation of Church and State. Actually, the Constitution does not mention this principle. In fact, it does not contain the word "church," nor yet the word "state" in the generic sense except in the Second Amendment, in which a "well regulated militia" is asserted to be "necesary to the security of a free state"; even the word "separation" fails to put in an appearance. These singular omissions-singular, if what the Framers wanted was "Separation of Church and State" in the Court's understanding of it-are now supplied by the Court by the interpretation which it affixes to the "establishment of religion" clause of the First Amendment. The Court's theory, which was stated in the first instance by Justice Black in his opinion for the Court in the New Jersey Bus case, is that, under this clause, supplemented by the word "liberty" of the Fourteenth Amendment, "Neither a state nor the Federal Government can [I] set up a church"; [2] "pass laws which aid one religion, 
[3] aid all religions, or [4] prefer one religion over another."20 For this reading of the clause the Court relies primarily on historical data. Do historical data, on the whole, sustain it? The answer is, not in such a way or such a sense as to vindicate the McCollum decision.

So far as the National Government is concerned, the first of the above four propositions is true; originally, indeed, it came near being the whole truth; as to the states it is not, as we shall see, necessarily true even today. Of the remaining assertions, the second may be ignored as ambiguous; the third is untrue historically; the fourth is true. In a word, what the "establishment of religion" clause of the First Amendment does, and all that it does, is to forbid Congress to give any religious faith, sect, or denomination a preferred status; and the Fourteenth Amendment, in making the clause applicable to the states, does not add to it, but logically curtails it.

Where, then, did Justice Black get his confident reading of the "establishment of religion" clause? He got it from Justice Rutledge's dissenting opinion in the New Jersey Bus case, which in turn is based largely on James Madison's Memorial and Remonstrance Against Religious Assessments of $1785 .{ }^{27}$ At that time-four years before the First Amendment was framed-a proposal was pending in the Virginia Assembly to levy a tax for the benefit of "teachers of the Christian religion." The father of the measure was Patrick Henry, but it was also supported outside the Assembly by Washington, Marshall, and other great names. Madison, on the other hand, with the recent successful fight for the disestablishment of the Episcopal Church in mind, fought the measure tooth and nail, fearing that if it was enacted that body would have its foot in the stirrup for a fresh leap into the saddle. The keynote of the Remonstrance, which summed up his opposition, is sounded in the following passage;

Who does not see that the same authority which can establish Christianity, in exclusion of all other Religions, may establish with the same ease any particular sect of Christians, in exclusion of all other Sects? That the same authority which can force a citizen to contribute three pence only of his property for the support of any one establishment, may force him to conform to any other establishment in all cases whatsover? ${ }^{28}$

As those very words show, however, Madison's conception of an "establishment of religion" in 1785 was precisely that which I have set forth above-a religion enjoying a preferred status. The same conception, moreover, underlies the state constitutions of the day, when they deal with the subject. ${ }^{20}$ It also underlies all but one

${ }^{20}$ Everson v. Board of Education, supra note 13 , at $x_{5}$.

${ }^{27}$ Id. at 63 ff, quoting II ThE Writings of JAMEs Madison I83-1gI (Hunt ed. igor).

${ }^{28}$ Justice Rutledge's dissenting opinion in Everson v. Board of Education, stupra note 13, at 65.66, quoting II The Writings of JaMes Madison I83, I86 (Hunt ed. 1901).

${ }^{29}$ See I Francis Newton Thorpe, The Federaz and State Constitumons, Colonial Charters, and Other Organic Laws of the States, Territories, and Colonies Now or Hereafter Forming the United States of AMERICa 567 (Dela); III id. 1890 (Mass.); IV id. 2454 (N. H.); V id. 2597 (N. J.), 2636 (N. Y.), 2793 (N. C.); VI id. 3255 (S. C.). 
of the proposals from the states which led to the framing of the First Amendment in the first Congress. Thus Virginia proposed that "no particular religious sect or society ought to be favored or established, by law, in preference to others"-a formula which North Carolina reiterated word for word, and which New York reiterated save for the word "particular." Only New Hampshire, concerned for her own "establishment," wanted a broader prohibition, one that would keep Congress out of the field of religion entirely. ${ }^{30}$

But, it may well be asked, what bearing do the views which Madison advanced in 1785 in a local political fight regarding the subject of religious liberty in Virginia have on the question of the meaning of the First Amendment? Justice Rutledge's theory is (I) that Madison was the author of the First Amendment, and (2) that he must have intended by the ban which is there imposed on Congress's legislating "respecting an establishment of religion" to rule out the kind of legislation which he had opposed in Virginia four years earlier. Neither of these positions is correct.

As originally introduced into the House of Representatives by Madison, the proposal from which the religion clauses of the First Amendment finally issued read. as follows:

The civil rights of none shall be abridged on account of religious belief or worship, nor shall any national religion be established, nor shall the full and equal rights of conscience be in any manner, or on any pretext, infringed. ${ }^{31}$

These words Madison later elucidated thus:

... he apprehended the meaning of the words to be, that Congress should not establish a religion, and enforce the legal observation of it by law, nor compel men to worship God in any manner contrary to their conscience ... if the word "national" was inserted before religion, it would satisfy the minds of honorable gentlemen. He believed that the people feared one sect might obtain a pre-eminence, or two combine together, and establish a religion to which they would compel others to conform. He thought if the word "national" was introduced, it would point the amendment directly to the object it was intended to prevent. ${ }^{32}$

In short, "to establish" a religion was to give it a preferred status, a pre-eminence, carrying with it even the right to compel others to conform. But in fact, before Madison's proposal was passed by the House and went to the Senate it had been changed to read: "Congress shall make no law establishing religion, or to prevent the free exercise thereof, or to infringe the rights of conscience"; and in the Senate this proposal was replaced by the following formula: "Congress shall make no law establishing articles of faith or a mode of worship or prohibiting the free exercise of religion." ${ }^{33}$ That is, Congress should not prescribe a national faith, a possibility

${ }^{30}$ III The Debates in the Several State Conventions on the Adoption of the Feperal ConstituTION 659 (Jonathan Elliott ed. 1836 ); I id. 326; IV id. 244, 25I. See also II id. 553.

ax I ANNALS of Cong. 434 (x789-I791).

${ }^{32}$ Id. at $730-73 \mathrm{I}$.

- ${ }^{3 a}$ Records of the United States Senate, September 9, 1789 , United States National Archives, cited 
which those states with establishments of their own-Massachusetts, New Hampshire, Connecticut, Maryland, and South Carolina-probably regarded with fully as much concern as those which had gotten rid of their establishments. And the final form of the First Amendment, which came from a committee of conference between the two houses, appears to reflect this concern. The point turns on the significance to be attached to the word "respecting," a two-edged word, which bans any law disfavoring as well as any law favoring an establishment of religion. As will be seen in a moment, Story's reading of the First Amendment makes "respecting" the pivotal word of the "no establishment" clause.

To come back for a moment to Madison. Thanks to his exertions, Henry's bill was defeated, and unquestionably his Remonstrance should be given considerable credit for this result. But political management also played a role, and no unimportant one. The great problem was to overcome the tremendous influence which Henry's oratory exerted in the Virginia Assembly. Writing Madison at this time from Paris, Jefferson said: "What we have to do, I think, is devotedly to pray for his death." Madison, however, had a better scheme. Relying on Henry's vanity, he concocted a movement to make him Governor, and Henry took the bait, hook, line, and sinker, thus automatically removing himself from the Assembly and destroying his brain-child. ${ }^{34}$

Yet it is probably due to his part in this fight that in his later years Madison carried the principle of separation of church and state to pedantic lengths, just as he did the principle of the separation of powers. In his essay on Monopolies, which was written after he left the presidency (probably long after), he put himself on record as opposed to the exemption of houses of worship from taxation, against the incorporation of ecclesiastical bodies with the faculty of acquiring property, against the houses of Congress having the right to choose chaplains to be paid out of national taxes, which, said he, "is a palpable violation of equal rights, as well as of Constitutional principles,"35 and also against chaplains in the Army and the Navy. He states, indeed, that as President he was averse to issuing proclamations calling for days of thanksgiving or prayer, but was in some instances prevailed upon to

\footnotetext{
in Appellees' Brief (Messrs. Franklin, Peterson, Rall, and Fisk) in the McCollum case, supra note 5. Here attention is drawn to the fact that the Virginia legislature postponed ratification of the third proposed amendment (Amendment I of the first ten amendments) until December 15, 1791 (III ANwals of CoNG. 54), by which time they had already received the approval of the required three-fourths of the state legislatures. The leaders in opposition to the First Amendment voiced their objections in the following terms: ". . . although it goes to restrain Congress from passing laws establishing any national religion, they might, nothwithstanding, levy taxes to any amount for the support of religion or its preachers; and any particular denomination of Christians might be so favored and supported by the general government, as to give it a decided advantage over the others, and in the process of time render it powerful and dangerous as if it was established as the national religion of the country." Evidently, as Appellees' Brief remarks, Virginians, who, after all, were the ones most familiar with the Virginia concept of religious freedom, did not interpret the First Amendment as living up to the spirit or the letter of the Virginia Bill for Establishing Religious Freedom. Brief, pp. 53-54.

${ }^{86}$ Irving Brant, James Madison, The Nationalist 345-346 (1948).

36 Fleet, Madison's "Detached [sic] Memoranda," 3 William and Mary Q. 534, 558 (3d Ser.) (I946).
} 
affix his name to proclamations of this character at the request of the houses of Congress. $^{36}$ In all these respects, of course, Madison has been steadily overruled by the verdict of practice under the Constitution, as the data assembled by Justice Reed . in his dissenting opinion show. ${ }^{\mathbf{3 7}}$

To conclude this-the Madisonian-phase of our subject: the importance attached by Justice Rutledge in the School Bus case to Madison's Memorial and Remonstrance of 1785 as interpretive of the First Amendment is obviously excessive. First, the Remonstrance antedated the framing of the amendment by four years; second, Madison himself never offered it as an interpretation of the amendment; third, he was not the author of the amendment in the form in which it was proposed to the state legislatures for ratification; fourth, even had he been, the Remonstrance itself is excellent evidence that "an establishment of religion" meant in 1785 a religion, sect, or denomination enjoying a privileged legal position; finally, Madison himself asserted repeatedly as to the Constitution as a whole that "the legitimate meaning of the Instrument must be derived from the text itself."38 Rejecting in a recent case the proposition that the Fourteenth Amendment, but more particularly the "due process" clause thereof, was intended to impose upon the States all of "the various explicit provisions of the first eight Amendments," Justice Frankfurter said: "Remarks of a particular proponent of the Amendment no matter how influential are not to be deemed part of the Amendment. What was submitted for ratification was his proposal, not his speech." ${ }^{39}$ And Madison was not even the proponent of the First Amendment in its final form!

But Justice Rutledge, and the Court also, urge the authority of Jefferson as an interpreter of the First Amendment, although, being in Paris at the time, Jefferson had no hand in framing it. The reason for the Court's deference to the third president is that in 1802 he wrote a letter to a group of Baptists in Danbury, Connecticut, in which he declared that it was the purpose of the First Amendment to build "a wall of separation between church and state." son's idea of such a wall? So far as it bears on the question of religion in the schools, it certainly does not support the position of the Court in the McCollum case. Dealing with the subject with respect to his own recently established University of Virginia, Jefferson wrote in I822:

It was not, however, to be understood that instruction in religious opinion and duties was meant to be precluded by the public authorities, as indifferent to the interests of society. On the contrary, the relations which exist between man and his Maker, and the duties resulting from those relations, are the most interesting and important to every human being, and most incumbent on his study and investigation. The want of instruction in the various creeds of religious faith existing among our citizens presents,

${ }^{36} I d$. at $55 \mathrm{I}-562$.

${ }^{37}$ McCollum v. Board of Education, supra note 5, at 253-255.

${ }^{88}$ III THE Works OF JAMES MAdison 228, 552 (Phila. I867).

${ }^{\text {so }}$ Adamson v. California, 332 U. S. 46,64 (1947).

${ }^{10}$ SaUl K. PaDover, The Complete JefFerson 518-519 (1943). 
therefore, a chasm in a general institution of the useful sciences . . . A remedy, however, has been suggested of promising aspect, which, while it excludes the public authorities from the domain of religious freedom, will give to the sectarian schools of divinity the full benefit the public provisions made for instruction in the other branches of science ... It has, therefore, been in contemplation, and suggested by some pious individuals, who perceive the advantages of associating other studies with those of religion, to establish their religious schools on the confines of the University, so as to give to their students ready and convenient access and attendance on the scientific lectures of the University; and to maintain, by that means, those destined for the religious professions on as high a standing of science, and of personal weight and respectability, as may be obtained by others from the benefits of the University. . . . Such an arrangement would complete the circle of the useful sciences embraced by this institution, and would fill the chasm now existing, on principles which would leave inviolate the constitutional freedom of religion, the most inalienable and sacred of all human rights, over which the people and authorities of this state, individually and publicly, have ever manifested the most watchful jealousy; and could this jealousy be now alarmed, in the opinion of the legislature, by what is here suggested, the idea will be relinquished on any surmise of disapprobation which they might think proper to express. ${ }^{41}$

And again:

. . . by bringing the sects together, and mixing them with the mass of other students, we shall soften their asperities, liberalize and neutralize their prejudices, and make the general religion a religion of peace, reason, and morality. ${ }^{42}$

The eager crusaders on the Court make too much of Jefferson's Danbury letter, which was not improbably motivated by an impish desire to heave a brick at the Congregationalist-Federalist hierarchy of Connecticut, whose leading members had denounced him two years before as an "infidel" and "atheist." A more deliberate, more carefully considered evaluation by Jefferson of the religious clauses of the First Amendment is that which occurs in his Second Inaugural: "In matters of religion, I have considered that its free exercise is placed by the constitution independent of the powers of the general government."43 In short, the principal importance of the amendment lay in the separation which it effected between the respective jurisdictions of state and nation regarding religion, rather than in its bearing on the question of the separation of church and state. For the rest, it is not irrelevant to the major subject opened up by the Court's decision to note that Jefferson regarded religion as "a supplement to law in the government of men," as "the alpha and omega of the moral law"-an attitude closely akin to that voiced in the Northwest Ordinance. ${ }^{44}$

Finally, I wish to adduce the evidence afforded by some important systematic

4I Id. at $957-958$.

12 I2 The Works of Thomas Jefrerson 272 (Ford ed. I905). These passages are both quoted by Justice Reed in a footnote, 333 U. S. 203, 245, $246 \mathrm{n}$. Ir.

${ }^{43}$ I Messages aNd PAPERS OF THE PRESIDENTS 379 (Richardson ed. I896).

${ }^{4} 7$ The Writings of Thomas Jefferson 339 (H. A. Washington ed. 1854); I id. at 545. For the latter reference, I am indebted to J. M. O'Neill, Retigion and Education UNDER the Constitution. This work, now in press, is a devastating assault upon the McCoillum decision from several angles. 
works on the subject of constitutional interpretation, as to the meaning of the term "an establishment of religion." The first of these, although the Court seems to have overlooked it entirely in its researches on the present occasion, carried vast authority a century ago, especially north of the Potomac. I refer to Story's Commentaries on the Constitution. Interestingly enough, with one important exception, Story's hardbitten New England views are quite in line in this instance with those of the Virginians. The exception is that according to Story, while the "no establishment" clause inhibited Congress from giving preference to any sect or denomination of the Christian faith, it was not intended thus to withdraw the Christian religion as a whole from the protection of Congress. Thus he wrote:

Probably at the time of the adoption of the Constitution, and of the amendment to it, now under consideration, the general, if not the universal sentiment in America was, that christianity ought to receive encouragement from the state, so far as was not incompatible with the private rights of conscience, and the freedom of religious worship. An attempt to level all religions, and to make it a matter of state policy to hold all in utter indifference, would have created universal disapprobation if not universal indig. nation. ${ }^{45}$

Nor was it the purpose of the Amendment to discredit state establishments of religion, but simply "to exclude from the National Government all power to act on the subject."

The situation ... of the different states equally proclaimed the policy, as well as the necessity of such an exclusion. In some of the states, episcopalians constituted the predominant sect; in others, presbyterians; in others, congregationalists; in others, quakers; and in others again, there was a close numerical rivalry among contending sects. It was impossible, that there should not arise perpetual strife and perpetual jealousy on the subject of ecclesiastical ascendency, if the national government were left free to create a religious establishment. The only security was in extirpating the power. But this alone would have been an imperfect security, if it had not been followed up by a declaration of the right of the free exercise of religion, and a prohibition (as we have seen) of all religious tests. Thus, the whole power over the subject of religion is left exclusively to the state governments, to be acted upon according to their own sense of justice, and the state constitutions; and the Catholic and the Protestant, the Calvinist and the Arminian, the Jew and the Infidel, may sit down at the common table of the national councils, without any inquisition into their faith, or mode of worship. ${ }^{46}$

A generation later Cooley's famous work on Constitutional Limitations appeared, the province of which is the constitutional restraints imposed by the state constitutions of that date on the state legislatures. In striking contrast to the passage just quoted from Story, Cooley's work records the disappearance of religious establishments from the state constitutions. His conception of "an establishment of religion" is, however, still the same as that of Story, Madison, and Jefferson, viz., "a sect . . .

${ }^{40}$ Joseph Story; Commentaries on the Constitution $§ 1874$ (1833).

10 Id. $\$ 1879$. 
favored by the State and given an advantage by law over other sects."47 And in his later Principles of Constitutional Law, Cooley is more explicit: "By establishment of religion is meant the setting up or recognition of a state church, or at least the conferring upon one church of special favors and advantages which are denied to others [citing I Tuck. Bu. Comm., App. 296; 2 id., App. Note G.]. It was never intended by the Constitution that the Government should be prohibited from recognizing religion-where it might be done without drawing any invidious distinctions between different religious beliefs, organizations, or sects."

\section{III}

All in all, it is fairly evident that Justice Rutledge sold his brethren a bill of goods when he persuaded them that the "establishment of religion" clause of the First Amendment was intended to rule out all governmental "aid to all religions." However, the First Amendment, taken by itself, is binding only on Congress; and the legislation involved in the $\mathrm{McC}$ Collum case was state legislation. The immediate basis of the decision in this case was, in fact, the "due process" clause of the Fourteenth Amendment; or more strictly speaking, the word "liberty" there. In other words, the theory of the case is that the Fourteenth Amendment renders the ban of the First Amendment on an establishment of religion applicable also to the states. Whence came this theory; and to what, logically, does it lead?

I shall deal with these questions in a moment. But first I wish to comment briefly on Justice Frankfurter's supplemental opinion in the McCollum case, in which he is joined by three other justices. For while the opinion throws no additional light on the meaning of the "establishment of religion" clause, it does have bearing on the broader subject of religion in the schools.

The opinion is a well-documented sketch of the secularization of public school education in the United States, a reform effected-so far as it has been effectedpurely by the political process, unaided up to this point by the Supreme Court. An outstanding figure in the fight on sectarianism in the schools was Horace Mann, who lived and wrought in Massachusetts in the second quarter of the last century. Of him Justice Frankfurter writes:

In Massachusetts, largely through the efforts of Horace Mann, all sectarian teachings were barred from the common school to save it from being rent by denominational conflict. The upshot of these controversies, often long and fierce, is fairly summarized by saying that long before the Fourteenth Amendment subjected the States to new limitations, the prohibition of furtherance by the State of religious instruction became the guiding principle; in law and feeling, of the American people. ${ }^{48}$

This account of things requires some amplifying. Any implication that he was

${ }^{47}$ Cooley, Constitutionar Limitations" 469 (2d ed. $187 \mathrm{x}$ ).

${ }^{47 a}$ Cooley, Principles of Consitututional Law 224-225 (3d ed. 1898 ). It is perhaps worth noting that it is in Tucker's Blackstone ( 1803 ) that Madison's and Jefferson's Virginia and Kentucky Resolutions were first elevated to the rank of an authoritative gloss on the Constitution.

${ }^{48}$ McCollum v. Board of Education, supra note 5, at 215. 
totally opposed to religious instruction in the schools Mann himself would have denied vehemently. Summing the matter up, Culver writes in his authoritative work on the subject:

It is true that Mr. Mann stood strongly for a "type of school with instruction adapted to democratic and national ends." But it is not quite just to him to contrast this type of school with the school adapted to religious ends, without defining terms. Horace Mann was opposed to sectarian doctrinal instruction in the schools, but he repeatedly urged the teaching of the elements of religion common to all of the Christian sects. He took a firm stand against the idea of a purely secular education, and on one occasion said he was in favor of religious instruction "to the extremest verge to which it can be carried without invading those rights of conscience which are established by the laws of God, and guaranteed to us by the Constitution of the State." At another time he said that he regarded hostility to religion in the schools as the greatest crime he could commit. Lest his name should go down in history as that of one who had attempted to drive religious instruction from the schools, he devoted several pages in his final Report-the twelfth-to a statement in which he denied the charges of his enemies. ${ }^{49}$

At another point, Justice Frankfurter quotes President Grant's "famous remarks" in I875 to a convention of the Army of Tennessee, and his message to Congress of the same year, asking for a constitutional amendment which, among other things, would forbid the use of public funds for sectarian education, and attacking the exemption of church property from taxation..$^{50}$ Acting on these suggestions James G. Blaine introduced a resolution providing that "no State shall make any law respecting an establishment of religion" and prohibiting any appropriation of public school money by any state to sectarian schools. The proposal was adopted by the House overwhelmingly, but was lost in the Senate. ${ }^{51}$ Down to $\mathrm{rg29}$ it had been reintroduced some twenty times, without result. The proposal assumes, of course, that it was necessary in order to fill a gap in the Constitution. Conversely, the Court's reading of the "due process" clause of the Fourteenth Amendment in the McCollum case assumes that any such amendment would be superfluous.

That the Fourteenth Amendment would make the Bill of Rights applicable to the states was frequently asserted in the congressional debates on the former, but this circumstance lends little if any support to the holding in the McCollum case. For one thing, the Court can hardly rely on it and at the same time reject the conception of the "establishment of religion" clause which prevailed in 1868 . If history is to be followed on the one point, it cannot fairly be abandoned on the other. Again,

19 Rammond B. Culver, Horace Mann and Religion in the Massachusetts Public Schools 235 (1929). With this statement of Mann's position it is interesting to compare the following extract from a colloquy of Justice Frankfurter with counsel for the School Board, in the course of the argument at Washington: "Mr. Justice Frankfurter. I put my question again: We have a school system of the United States on the one hand, and the relation it has to the democratic way of life. On the other hand we have the religious beliefs of our people. The question is whether any kind of scheme which introduced religious teaching into the public school system is the kind of thing we should have in our democratic institutions." J. M. O'NeIL, op. cit. stipra note 44, at 234.

${ }^{80}$ McCollum v. Board of Education, supra note 5, at 218 .

${ }^{6}$ M. A. Musmanno, Proposed Amendments to the Constitution 182 (I929). 
the expectations of its framers regarding the operation of the amendment rested mainly on two ideas, both of which were early discredited by the Court itself. The first of these was that the "privileges and immunities of citizens of the United States" protected by the amendment covered the whole realm of civil rights; the second was that Congress's legislative power under Section $V$ of the amendment would be equally extensive. Thus the application of the Bill of Rights to the states would be effected by congressional action; the notion that the Court would have any hand in the business was not widely entertained.51a

The Court itself, however, had different ideas. In the famous Slaughter House Cases $^{52}$ of 1873 it adopted a conception of "privileges and immunities of citizens of the United States" which extruded all "fundamental" rights from the term. In the Civil Rights Cases $^{53}$ ten years later it pared down Congress's powers under the fifth section of the amendment to the bare disallowance of state legislation violative of the first section-a function better left to the processes of judicial review. The subsequent judicial history of the Fourteenth Amendment has in the main been the history of the Court's interpretation of the due process clause; but of this history the only phase of interest in the present connection is that which involves the word "liberty" in that clause. In 1898 , thirty years after the adoption of the amendment, the Court, responding to the pressure of preponderant legal opinion in the country, at last adopted a definition of "liberty" embracing "freedom of contract," and especially freedom of contract in the sphere of employer-employee relations. ${ }^{\text {"t }}$ More expansive conceptions of the term, on the other hand, it steadily repelled throughout the next quarter of a century. ${ }^{55}$ Even as late as 1922 we find it using the following words:

Neither the Fourteenth Amendment nor any other provision of the Constitution of the United States imposes upon the States any restrictions about "freedom of speech" or the "liberty of silence."

Following the first World War, however, the Court began shifting its position; and in the notable case of Pierce $v$. Society of Sisters, ${ }^{67}$ decided in Ig25, it held that the word "liberty" in the Fourteenth Amendment protects the rights of parents to guide the education of their children, and hence the right to send them to

61* In his dissenting opinion in Adamson v. California, 332 U. S. ${ }_{4}^{6}$, 68f. (1947), Justice Black argues that the Fourteenth Amendment adopts the Bill of Rights in toto and quotes from the congressional debates on the former to prove the point, relying especially on speeches by Representative Bingham of Ohio and Senator Howard of Michigan. He overlooks the fact that both these high authorities expected that the application of the Bill of Rights to the states would be effected by congressional legislation. See the Appendix compiled by Justice Black to his opinion, 332 U. S. 92-123, especially at pp. $93,94,95,97,98$, xor, I06, I07, II0, II2, II4, II5, II7, and 118 .

Slaughter House Cases, 16 Wall. 36 (U. S. 1873).

${ }^{83}$ Civil Rights Cases, 109 U. S. 3 (1883).

s Holden v. Hardy, I69 U. S. 366 (1898).

${ }^{50}$ On this and the following paragraph, see my 'Liberty Agninst Government 134-168 (1948).

${ }^{50}$ Prudential Insurance Co. v. Cheek, 259 U. S. 530, 543 (Ig22).

${ }^{87} 268$ U. S. 510 (I925). 
parochial schools rather than the public schools, if they so choose. And on this basis, the Oregon compulsory school law, which made it impossible, practically, for children to attend parochial schools, was pronounced unconstitutional. As I shall point out in a moment, the holding in the McCollum case is logically incompatible with the decision just mentioned. Finally, in this same year, 1925, the Court, in the well-known Gitlow case, 58 tentatively adopted the thesis that the word "liberty" in the Fourteenth Amendment includes freedom of speech and press as recognized in the First Amendment; and this tentative thesis has since become a firm part of the Court's jurisprudence. In many recent cases, most of which involve Jehovah's Witnesses, the same doctrine has, moreover, been applied to religious liberty. ${ }^{59}$

That the Court was warranted by a considerable line of recent decisions in taking the position in the McCollum case that if the "released time" program there involved amounted to an invasion of anybody's freedom of religion it was unconstitutional, is clear. Indeed, whether the program did this or not was, properly speaking, the only question before the Court; and the talk about "an establishment of religion" was entirely beside the point unless the "released time" program of the Champaign schools involved an establishment of religion of such a nature as to deprive the plaintiff in the case of feedom of religion. That is to say, the Fourteenth Amendment does not authorize the Court to substitute the word "state" for "Congress" in the ban imposed by the First Amendment on laws "respecting an establishment of religion." So far as the Fourteenth Amendment is concerned, states are entirely free to establish religions, provided they do not deprive anybody of religious liberty. It is only liberty that the Fourteenth Amendment protects. And in this connection it should not be overlooked that contemporary England manages to maintain as complete freedom of religion as exists in this country alongside an establishment of religion, although originally that establishment involved a ban upon all other faiths. ${ }^{60}$

Vital, therefore, to the Court's argument in the McCollum case is the proposition that such children in the Champaign schools as came under the program were coerced to do so by virtue of the fact that they were gathered there-"recruited" is the Court's word-in consequence of the state compulsory school law. The answer is that no children were admitted to the program unless their parents formally requested that they be, and the choice of the parent must be imputed to the child. There is still, of course, the coercion exercised by the parent, but it seems unlikely that the Court is out to emancipate children from their parents!

${ }^{58}$ Gitlow v. New York, 268 U. S. 652 (r925).

"O Cantwell v. Connecticut, 310 U. S. 296 (I940); West Virginia State Board of Education v. Barnette, 319 U. S. 624 (1943), and cases there cited.

${ }^{60}$ In the Cantwell case, cited above, it is stated incidentally (p. 303) that the Fourteenth Amendment makes the "establishment of religion" clause of the First Amendment operate with the same force on the states as it does on Congress; but this statement is based on the idea that an establishment signifies "compulsion by law of the acceptance of ... [a] creed or the practice of ... [a] form of worship." Ibid. Story, on the other hand, holds that an ecclesiastical establishment may be perfectly compatible with full freedom of religion for all sects. Joseph Story, Commentaries on the Constiturtion $\$ 1872$ (I833). 
This is not to say, however, that there was no question of coercion involved in this case and involved in a very significant way, although one which appears to have escaped entirely the careful diligence of the Court. I recur to my reference a paragraph or two back to the decision in 1925 in Pierce v. Society of Sisters, ${ }^{01}$ in which an Oregon compulsory school law was set aside as impairing the right of parents, who wished their children to attend parochial schools, to guide the education of their children. Two observations seem called for. In the first place, it is an inevitable implication of the case that compulsory school laws which permit attendance at parochial schools are constitutional, notwithstanding the compulsion which is thereby lent such schools in "recruiting" pupils. This compulsion is, in fact, immensely more evident than that which was put upon pupils to avail themselves of the Champaign "released time" program. In the second place, the parental right which was vindicated in the Pierce case, whatever else it is, must also be reckoned to be an element of the right which the Constitution guarantees to all to "the free exercise" of their religion. The question accordingly arises whether this right is confined to parents who can afford to send their children to parochial or other private schools; whether, in other words, parents who must for financial or other reasons send their children to the public schools have no right to guide their education to the extent of demanding that the education there available shall include some religious instruction, provided nobody's freedom of religion is thereby impaired? All in all, it seems clear that the Court, by its decision in the McCollum case, has itself promulgated a law prohibiting "the free exercise" of religion, contrary to the express prohibition of the First Amendment!

To summarize the argument against the decision in the McCollum case: In the first place, the justification for the Court's intervention was trivial and directly violative of restrictions hitherto existing on judicial review. In the second place, the decision is based, as Justice Reed rightly contends, ${ }^{62}$ on "a figure of speech," the concept of "a wall of separation between Church and State." Thirdly, leaving this figure of speech to one side, the decision is seen to stem from an unhistorical conception of what is meant by "an establishment of religion" in the First Amendment. The historical record shows beyond peradventure that the core idea of "an establishment of religion" comprises the idea of preference; and that any act of public authority favorable to religion in general cannot, without manifest falsification of history, be brought under the ban of that phrase. Undoubtedly the Court has the right to make history, as it has often done in the past; but it has no right to remake it. In the fourth place, the prohibition on the establishment of religion by Congress is not convertible into a similar prohibition on the states, under the authorization of the Fourteenth Amendment, unless the term "establishment of religion" be given an application which carries with it invasion of somebody's freedom of religion, that is, of "liberty." Finally, the decision is accompanied by opinions and by a mandate

\footnotetext{
'1 See note 57 stspra.

${ }^{02}$ McCollum v. Board of Education, supra note 5 , at 247.
} 
which together have created great uncertainty in the minds of governing bodies of all public educational institutions. And, of course, as is always the case, the Court's intervention is purely negative. It is incapable of solving the complex problem with which forty-six states and 2,200 communities have been struggling by means of the "released time" expedient. With the utmost insouciance the Court overturns or casts under the shadow of unconstitutionality the "conscientious attempt" of hundreds of people to deal with what they have considered to be a pressing problem in a way that they have considered to be fair and just to all.

Finally, this question may be asked: Is the decision favorable to democracy? Primarily democracy is a system of ethical values, and that this system of values so far as the American people are concerned is grounded in religion will not be denied by anybody who knows the historical record. And that the agencies by which this system of values has been transmitted in the past from generation to generationthe family, the neighborhood, the church-have today become much impaired will not be seriously questioned by anybody who knows anything about contemporary conditions. But what this all adds up to is that the work of transmission has been put more and more upon the shoulders of the public schools. Can they, then, do the job without the assistance of religious instruction? At least, there seems to be a widely held opinion to the contrary.

I wonder just how the shade of Justice Holmes would comment on this decision. I can imagine the late Justice repeating some words which he used in a dissenting opinion in I92r:

There is nothing that I more deprecate than the use of the Fourteenth Amendment beyond the absolute compulsion of its words to prevent the making of social experiments that an important part of the community desires, in the insulated chambers afforded by the several States, even though the experiments may seem futile or even noxious to me and to those whose judgment I most respect. ${ }^{83}$

Indeed, he might even feel called upon to repeat his gibe about judges being "naif, simple-minded men"64 one mark of naiveté being a preference for slogans over solutions.

And what would the Court answer? Perhaps it might adopt the words of Justice Jackson in a recent case:

We [the Court] act in these matters not by the authority of our competence but by force of our commissions. We cannot, because of modest estimates of our competence in such specialties as public education, withihold the judgment that history authenticates as the function of this Court when liberty is infringed. ${ }^{65}$

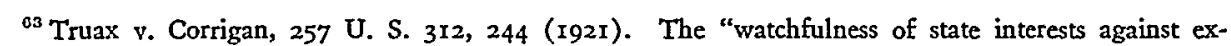
uberant judicial restrictions," which Holmes gave expression to in the passage just quoted, is praised by Justice Frankfurter with warm enthusiasm in his Mr. Justice Holmes and the Supreme Court 86-88 (1938). See also his recent opinion in Adamson v. California 332 U. S. 46, 59, 62.

- Holmes, Collected Legal Papers 295 (192r).

of West Virginia State Board of Education v. Barnette, supra note 59, at 640 . 
This is a plea in confession and avoidance which can by no means be granted. It is not to be presumed that the Constitution puts burdens on the Court in the discharge of which with appropriate modesty it must still risk disaster for the country. The decision in the McCollum case, however, is not a "modest" decision. Instead it is to be grouped with those high-flying tours de force in which the Court has occasionally indulged, to solve "forever" some teasing problem-slavery, for example, in the Dred Scott case ${ }^{88}$-or to correct, as in the Pollock case, ${ }^{67}$ "a century of error."

In my opinion the Court would act wisely to make it clear at the first opportunity that it does not aspire to become, as Justice Jackson puts it, "a super board of education for every school district in the nation." ${ }^{\text {B }}$

${ }^{\circ 0}$ Dred Scott v. Sanford, x9 How. 393 (U. S. I856).

${ }^{67}$ Pollock v. Farmers Loan and Trust Co., 157 U. S. 429 (1895).

${ }^{68}$ McCollum v. Board of Education, supra note 5, at 237. 